\title{
Synthesis of allylic trifluoromethyl ketones and their activity as inhibitors of the sex pheromone of the leopard moth, Zeuzera pyrina L. (Lepidoptera: Cossidae)
}

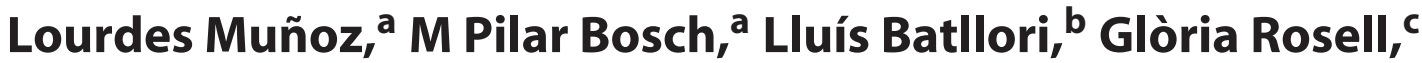 \\ Dolors Bosch, ${ }^{\mathrm{d}}$ Angel Guerrero ${ }^{\mathrm{a}}$ and Jesús Avillad*
}

\begin{abstract}
BACKGROUND: Trifluoromethyl ketones (TFMKs), structurally related to the pheromones, are good inhibitors of pheromone communication in insects. To determine their activity on Zeuzera pyrina L. (Lepidoptera: Cossidae), a polyphagous pest, the authors have prepared two diunsaturated TFMK analogues of the major (3) and the minor (4) pheromone components, and two monounsaturated ones $(5,6)$. Their biological activity in electroantennogram (EAG), wind tunnel and field tests is presented.
\end{abstract}

RESULTS: The synthetic strategy to obtain the allylic TFMKs 3 and 5 is based on the reactions of diene 10 and 1-octadecene with trifluoroacetaldehyde ethyl hemiacetal, followed by Dess-Martin oxidation of the resulting homoallylic trifluoromethyl alcohols. In EAG, topical application of analogues 3 and 4 on male antennae significantly reduced the pheromone response. In the wind tunnel, compound 4 reduced the number of contacts with the pheromone source. In the field, traps baited with mixtures of pheromone and inhibitors captured significantly fewer males than the pheromone alone.

CONCLUSION: An efficient synthesis of allylic TFMKs is reported, with good overall yield, regiospecificity and diastereoselectivity. These compounds are good inhibitors of the pheromone in electrophysiology, wind tunnel and field tests. The results show the importance of two unsaturations at positions 2 and 13 of the trifluoroacyl group in the structure of the analogues, the latter being critical for inhibitory activity.

(c) 2011 Society of Chemical Industry

Keywords: Zeuzera pyrina; leopard moth; pheromone inhibition; allylic trifluoromethyl ketones

\section{INTRODUCTION}

The leopard moth Zeuzera pyrina L. (Lepidoptera: Cossidae) is a worldwide distributed wood borer, mainly present in the southern regions of Europe, Asia and North Africa. The larvae seriously damage pear, apple, hazel, cherry and olive trees by excavating galleries in shoots, branches and the main trunk that can eventually cause the death of the tree. Its sex pheromone, emitted by adult females, is a mixture of $(E, Z)$-2,13-octadecadienyl acetate $(\mathbf{1}),(E, Z)$ 3,13-octadecadienyl acetate (2) and (Z)-13-octadecenyl acetate in a $78-86: 4: 18-10$ ratio (Fig. 1). ${ }^{1-3}$ A $96: 4$ mixture of compounds 1 and $\mathbf{2}$ is used for male flight monitoring, and for population control by mass trapping and mating disruption. Both techniques have been applied successfully in several countries, but the best results have been achieved by mating disruption. ${ }^{4-7}$ Trifluoromethyl ketones (TFMKs) are known to inhibit a number of esterases and proteases, such as acetylcholinesterase, chymotrypsin, human liver carboxylesterases ${ }^{8,9}$ and, particularly, the antennal esterases present in insect olfactory tissues. , $^{80-12}$ TFMKs act through the formation of a stable hemiacetal of tetrahedral geometry with a serine residue of the enzyme. ${ }^{13,14}$

Following work aimed at developing pheromone perception inhibitors of insect pests, ${ }^{15-17}$ the authors report in the present paper on the chemical synthesis and the inhibitory activity of TFMKs 3 to 6 (Fig. 1), analogues of the pheromone components of the leopard moth Z. pyrina, in electrophysiology, wind tunnel and field tests. TFMKs $\mathbf{3}$ and $\mathbf{4}$ are analogues of the major (1) and of the minor (2) components of the pheromone respectively. TFMKs $\mathbf{5}$ and $\mathbf{6}$ are analogues of both components, with only one double bond; they were synthesised and tested in order to ascertain the importance of the double unsaturation. Particularly interesting are the allylic TFMKs $\mathbf{3}$ and $\mathbf{5}$, for which some of the

* Correspondence to: Jesús Avilla, Crop Protection Department, Centre UdL-IRTA for R\&D, Rovira Roure 191, 25198 Lleida, Spain.E-mail:jesus.avilla@irta.es

a Departament de Quimica Biològica i Modelització Molecular (IQAC-CSIC), Barcelona, Spain

b Servei de Sanitat Vegetal, Departament d'Agricultura, Ramaderia i Pesca, Girona, Spain

c Department of Pharmacology and Therapeutic Chemistry, Faculty of Pharmacy, University of Barcelona, Barcelona, Spain

d Crop Protection Department, Centre UdL-IRTA for R\&D, Lleida, Spain 


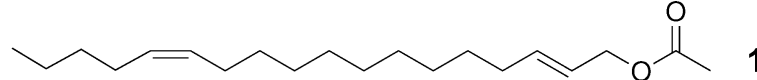

$$
\begin{aligned}
& \mathrm{NON}^{2}
\end{aligned}
$$

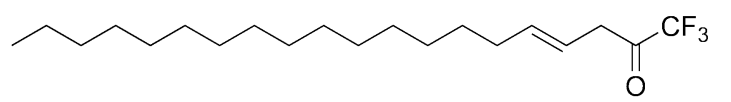

Figure 1. List of chemical structures.

known synthetic methods for TFMKs have proved unsuitable. ${ }^{18-20}$ An efficient methodology is presented for obtaining allylic TFMKs, based on the addition of terminal olefins to trifluoroacetaldehyde ethyl hemiacetal in the presence of a Lewis acid as catalyst.

\section{EXPERIMENTAL}

\subsection{General}

The pheromone blend (pheromone, hereinafter) containing a mixture of $(E, Z)-2,13$-octadecadienyl acetate $(\mathbf{1})$ and $(E, Z)-3,13-$ octadecadienyl acetate (2) in a 96:4 ratio, (Z)-13-hexadecenal, $(Z, E)-3,13-o c t a d e c a d i e n o l$ and (Z)-11-hexadecen-1-ol were kindly provided by SEDQ, SA (Barberá del Vallés, Barcelona, Spain). 1-Octadecene was commercially available from Sigma-Aldrich Química (Madrid, Spain). (Z)-1-Bromo-11-hexadecene (7) was synthesised from (Z)-11-hexadecen-1-ol following a procedure previously described by the present authors. ${ }^{21}$ Trifluoromethyl ketones $\mathbf{4}$ and $\mathbf{6}$ were prepared from the corresponding alcohol precursors by conversion into the corresponding iododerivatives and subsequent trans-metallation reactions followed by treatment with ethyl trifluoroacetate. ${ }^{19}$ All reactions involving air- or moisture-sensitive materials were carried out under Ar. All solvents were dried and distilled according to standard procedures. IR spectra were recorded on a Bomem MB-120 (Bomem Inc., Quebec, Canada) or Nicolet Avatar 360 FT-IR spectrometer (Thermo Electron Inc., Madison, WI). NMR spectra were recorded at $300 \mathrm{MHz}$ for ${ }^{1} \mathrm{H}$, at $75 \mathrm{MHz}$ for ${ }^{13} \mathrm{C}$ and at $282 \mathrm{MHz}$ for ${ }^{19} \mathrm{~F}$ on a Varian Unity $300 \mathrm{MHz}$ spectrometer (Varian Inc., Palo Alto, CA). Mass spectra (MS) were obtained on a Fisons MD 800 instrument (Thermo Fisher Scientific, Waltham, MA). Elemental analyses $(C, H, N, F)$ were determined on a Carlo Erba-1108 (Carlo Erba Instruments, Milan, Italy) and on a Metrohm Titrando 808 analyser (Metrohm, Herisau, Switzerland). The electrophysiology tests were carried out on a commercial electroantennogram (EAG) apparatus (Syntech, Hilversum, The Netherlands).

\subsection{Synthesis of allylic TFMKs 3 and 5}

\subsection{1 (Z)-12-Heptadecene-1-nitrile (8)}

A mixture of (Z)-1-bromo-11-hexadecene (7) $(5.50 \mathrm{~g}, 18.13 \mathrm{mmol})$, $\mathrm{NaCN}(1.07 \mathrm{~g}, 21.76 \mathrm{mmol}), n$-tributylamine $(0.25 \mathrm{~mL})$ and $\mathrm{H}_{2} \mathrm{O}$ $(3.2 \mathrm{~mL})$ was heated at reflux for $4 \mathrm{~h}$, according to the procedure described by Apparu et al. ${ }^{22}$ The crude product was diluted with brine and extracted with hexane. The combined organic layers were dried with $\mathrm{MgSO}_{4}$ and the solvent was removed under reduced pressure. After purification by column chromatography (silica gel, hexane: ether $95: 5)$, the corresponding nitrile $8(4.25 \mathrm{~g}$, 94\%) was obtained as a colourless oil. ${ }^{1} \mathrm{H} \mathrm{NMR}\left(300 \mathrm{MHz}, \mathrm{CDCl}_{3}\right)$, $\delta(\mathrm{ppm}): 5.34(\mathrm{~m}, 2 \mathrm{H}) ; 2.32(\mathrm{t}, J=6.9 \mathrm{~Hz}, 2 \mathrm{H}) ; 2.01(\mathrm{~m}, 4 \mathrm{H}) ; 1.65$ $(\mathrm{m}, 2 \mathrm{H}) ; 1.35(\mathrm{bs}, 18 \mathrm{H}) ; 0.89(\mathrm{t}, J=6.9 \mathrm{~Hz}, 3 \mathrm{H}) .{ }^{13} \mathrm{C} \mathrm{NMR}(75 \mathrm{MHz}$, $\left.\mathrm{CDCl}_{3}\right), \delta$ (ppm): 129.8; 129.7; 119.8; 31.9; 29.7; 29.4; 29.2; 29.2; 28.7; 28.6; 27.1; 26.8; 25.3; 22.3; 17.0; 13.9. IR (film, NaCl) v: 3005, 2926, 2855, $1465 \mathrm{~cm}^{-1}$. MS (EI) $\mathrm{m} / \mathrm{z}(\%): 249\left(\mathrm{M}^{+}, 5\right) ; 206(11) ; 136$ (40); 122 (54); 97 (24); 83 (32); 69 (52); 55 (100); 41 (40). Elemental analysis: Calcd for $\mathrm{C}_{17} \mathrm{H}_{31} \mathrm{~N}: \mathrm{C}, 81.86 ; \mathrm{H}, 12.53 ; \mathrm{N}, 5.62$. Found: $\mathrm{C}$, $82.04 ; \mathrm{H}, 12.46 ; \mathrm{N}, 5.45$.

\subsection{2 (Z)-12-Heptadecenal (9)}

A similar procedure to that described by Villuendas et al..$^{19}$ was used. Thus, a mixture of (Z)-12-heptadecene-1-nitrile $(4.25 \mathrm{~g}$, $17.04 \mathrm{mmol}), 1 \mathrm{MDIBAH}$ solution in hexane $(20.45 \mathrm{~mL}, 20.45 \mathrm{mmol})$ and anhydrous hexane $(100 \mathrm{~mL})$ was stirred at $-78^{\circ} \mathrm{C}$ under Ar. After stirring for $5 \mathrm{~h}$ at $-78^{\circ} \mathrm{C}$, the reaction mixture was allowed to warm to $0^{\circ} \mathrm{C}$ and $\mathrm{NH}_{4} \mathrm{Cl}$ saturated solution $(200 \mathrm{~mL}$ ) was added. The organic phase was decanted and the aqueous layer was extracted with hexane. The aqueous phase was acidified with $1 \mathrm{M} \mathrm{HCl}$ and extracted with diethyl ether. The combined organic phases were dried with $\mathrm{MgSO}_{4}$ and the solvent was removed under vacuum. The residue was purified by column chromatography on silica gel, eluting with hexane: ether $(95: 5)$, to obtain aldehyde $9(3.48 \mathrm{~g}, 81 \%)$ as a colourless oil. ${ }^{1} \mathrm{H} \mathrm{NMR}\left(300 \mathrm{MHz}, \mathrm{CDCl}_{3}\right), \delta$ (ppm): $9.75(\mathrm{t}, J=1.8 \mathrm{~Hz}, 1 \mathrm{H}) ; 5.34(\mathrm{~m}, 2 \mathrm{H}) ; 2.41$ (td, $J_{1}=7.2 \mathrm{~Hz}$, $\left.J_{2}=1.8 \mathrm{~Hz}, 2 \mathrm{H}\right) ; 2.01(\mathrm{~m}, 4 \mathrm{H}) ; 1.62(\mathrm{~m}, 2 \mathrm{H}) ; 1.30(\mathrm{bs}, 18 \mathrm{H}) ; 0.89(\mathrm{t}$, $J=6.9 \mathrm{~Hz}, 3 \mathrm{H}) .{ }^{13} \mathrm{C}$ NMR $\left(75 \mathrm{MHz}, \mathrm{CDCl}_{3}\right), \delta$ (ppm): 202.9; 129.8; $43.9 ; 31.9 ; 29.7 ; 29.5 ; 29.5 ; 29.4 ; 29.3 ; 29.2 ; 29.1 ; 27.1 ; 26.9 ; 22.3$; 22.0; 14.0. IR (film, NaCl) v: 3005, 2926, 2854, $1728,1465 \mathrm{~cm}^{-1}$. MS (EI) $\mathrm{m} / \mathrm{z}$ (\%): 234 (3); 98 (26); 95 (28); 83 (31); 81 (35); 69 (43); 67 (33); 55 (100); 43 (24); 41 (42). Elemental analysis: Calcd for $\mathrm{C}_{17} \mathrm{H}_{32} \mathrm{O}$ : C, 80.88; $\mathrm{H}, 12.78$. Found: $\mathrm{C}, 80.97 ; \mathrm{H}, 12.58$.

\subsection{3 (Z)-1,13-Octadecadiene (10)}

To a suspension of methyltriphenylphosphonium bromide (1.25 g, $3.51 \mathrm{mmol})$ in anhydrous THF $(10 \mathrm{~mL})$ was added $1.4 \mathrm{M}$ of $n$-BuLi solution in hexane $(2.2 \mathrm{~mL}, 3.07 \mathrm{mmol})$. The resulting orange solution was stirred for $1 \mathrm{~h}$ and cooled to $-78^{\circ} \mathrm{C}$, and a solution of (Z)-12-heptadecenal $(0.50 \mathrm{~g}, 1.98 \mathrm{mmol})$ in THF $(5 \mathrm{~mL})$ was then slowly added. The reaction mixture was allowed to warm to room temperature and stirred for $2 \mathrm{~h}$. The solvent was evaporated, and the crude product was treated with $\mathrm{NH}_{4} \mathrm{Cl}$ saturated solution $(50 \mathrm{~mL})$ and extracted with hexane. The combined organic layers were washed with brine and dried $\left(\mathrm{MgSO}_{4}\right)$. After removal of the solvent, purification by column chromatography on silica gel, eluting with hexane, afforded diene $\mathbf{1 0}(0.39 \mathrm{~g}, 80 \%)$ as a colourless oil. ${ }^{1} \mathrm{H}$ NMR (300 MHz, $\left.\mathrm{CDCl}_{3}\right), \delta$ (ppm): 5.82 (ddt, $J_{1}=17.1 \mathrm{~Hz}$, $\left.J_{2}=10.2 \mathrm{~Hz}, J_{3}=6.6 \mathrm{~Hz}, 1 \mathrm{H}\right) ; 5.35(\mathrm{~m}, 2 \mathrm{H}) ; 4.99\left(\mathrm{ddt}, J_{1}=17.1 \mathrm{~Hz}\right.$, $\left.J_{2}=2.4 \mathrm{~Hz}, J_{3}=1.5 \mathrm{~Hz}, 1 \mathrm{H}\right) ; 4.93\left(\mathrm{ddt}, J_{1}=10.2 \mathrm{~Hz}, J_{2}=2.4 \mathrm{~Hz}\right.$, $\left.J_{3}=1.2 \mathrm{~Hz}, 1 \mathrm{H}\right) ; 2.02(\mathrm{~m}, 6 \mathrm{H}) ; 1.33(\mathrm{bs}, 20 \mathrm{H}) ; 0.90(\mathrm{t}, J=6.9 \mathrm{~Hz}, 3 \mathrm{H})$. $\left.{ }^{13} \mathrm{C} \mathrm{NMR} \mathrm{(75} \mathrm{MHz,} \mathrm{CDCl}_{3}\right), \delta$ (ppm): 139.3; 129.9; 129.8; 114.1; 33.8; 
$32.0 ; 29.8 ; 29.6 ; 29.5 ; 29.5 ; 29.3 ; 29.1 ; 28.9 ; 27.2 ; 26.9 ; 22.3 ; 14.0$. IR (film, NaCl) v: 3005, 2924, 2854, 1465, $909 \mathrm{~cm}^{-1}$. MS (EI) $\mathrm{m} / \mathrm{z}$ (\%): $250\left(\mathrm{M}^{+}, 4\right) ; 96(42) ; 82(54) ; 69$ (40); 55 (100). Elemental analysis: Calcd for $\mathrm{C}_{18} \mathrm{H}_{34}: \mathrm{C}, 86.32, \mathrm{H}, 13.68$. Found: $\mathrm{C}, 86.30 ; \mathrm{H}, 13.66$.

\subsection{4 (E,Z)-1,1,1-Trifluoro-4,15-eicosadien-2-ol (12)}

To a solution of diene $10(2.50 \mathrm{~g}, 9.98 \mathrm{mmol})$ in anhydrous $\mathrm{CH}_{2} \mathrm{Cl}_{2}(10 \mathrm{~mL})$ was added trifluoroacetaldehyde ethyl hemiacetal $(1.2 \mathrm{~mL}, 9.98 \mathrm{mmol})$, followed by slow addition of $\mathrm{BF}_{3} \cdot \mathrm{OEt}_{2}(3.8 \mathrm{~mL}$, $29.94 \mathrm{mmol}){ }^{23}$ The mixture was stirred at room temperature for $4 \mathrm{~h}$, treated with $10 \% \mathrm{HCl}$ and ice and extracted with $\mathrm{CH}_{2} \mathrm{Cl}_{2}$. The combined organic layers were washed with brine and dried $\left(\mathrm{MgSO}_{4}\right)$, and the solvent was removed. The crude product was purified by column chromatography on silica gel, eluting with hexane: ether $98: 2$, to afford the corresponding diunsaturated trifluoromethylcarbinol $12(2.61 \mathrm{~g}, 75 \%)$ with an 86:14 $E: Z$ ratio. Stereochemically pure $E$ isomer was obtained through a second column chromatography on $10 \% \mathrm{AgNO}_{3}$-impregnated silica gel, ${ }^{24}$ eluting with hexane: ether $(98: 2)$, to obtain stereomerically pure (E,Z)-1,1,1-trifluoro-4,15-eicosadien-2-ol (12) (2.20 g,63\%). ${ }^{1} \mathrm{HNMR}$ $\left(300 \mathrm{MHz}, \mathrm{CDCl}_{3}\right), \delta(\mathrm{ppm}): 5.65\left(\mathrm{dtt}, J_{1}=15.3 \mathrm{~Hz}, J_{2}=6.9 \mathrm{~Hz}\right.$, $\left.J_{3}=1.2 \mathrm{~Hz}, 1 \mathrm{H}\right) ; 5.37(\mathrm{~m}, 3 \mathrm{H}) ; 3.93(\mathrm{~m}, 1 \mathrm{H}) ; 2.38(\mathrm{~m}, 2 \mathrm{H}) ; 2.17(\mathrm{~d}$, $J=6.0 \mathrm{~Hz}, 1 \mathrm{H}) ; 2.03(\mathrm{~m}, 6 \mathrm{H}) ; 1.31$ (bs, $18 \mathrm{H}) ; 0.90(\mathrm{t}, J=6.9 \mathrm{~Hz}$, $3 \mathrm{H}) .{ }^{13} \mathrm{C}$ NMR $\left(75 \mathrm{MHz}, \mathrm{CDCl}_{3}\right), \delta$ (ppm): 136.8; 129.9; 124.9 (q, $\left.J=281 \mathrm{~Hz},-\mathrm{CH}(\mathrm{OH}) \mathrm{CF}_{3}\right) ; 122.4 ; 69.7$ (q, $\left.J=31 \mathrm{~Hz},-\mathrm{CH}(\mathrm{OH}) \mathrm{CF}_{3}\right)$; $33.3 ; 32.5 ; 31.9 ; 29.7 ; 29.5 ; 29.5 ; 29.4 ; 29.3 ; 29.2 ; 29.1 ; 27.2 ; 26.9$; $22.3 ; 14.0 .{ }^{19} \mathrm{~F} \mathrm{NMR}\left(282 \mathrm{MHz}, \mathrm{CDCl}_{3}\right), \delta(\mathrm{ppm}):-79.8(\mathrm{~d}, J=6.5 \mathrm{~Hz}$, $\mathrm{CH}(\mathrm{OH}) \mathrm{CF}_{3}$ ). IR (film, NaCl) v: 3404, 3006, 2930, 2853, 1466, 1278, $1173,969 \mathrm{~cm}^{-1}$. MS (EI) m/z (\%): 348 (M+, 19); 208 (29); 166 (79); 152 (20); 139 (41); 123 (39); 109 (79); 97 (77); 95 (90); 81 (92); 69 (87); 67 (94); 55 (100); 43 (65); 41 (96). Elemental analysis: Calcd for $\mathrm{C}_{20} \mathrm{H}_{35} \mathrm{~F}_{3} \mathrm{O}: \mathrm{C}, 68.93 ; \mathrm{H}, 10.12 ; \mathrm{F}, 16.36$. Found: $\mathrm{C}, 68.90 ; \mathrm{H}, 10.17 ; \mathrm{F}$, 16.49 .

\subsection{5 (E,Z)-1,1,1-Trifluoro-4,15-eicosadien-2-one (3)}

To a $15 \%$ solution of Dess-Martin periodinane ${ }^{25}$ in $\mathrm{CH}_{2} \mathrm{Cl}_{2}(16.82 \mathrm{~g}$, $5.95 \mathrm{mmol}$ ) was added dienol $12(0.83 \mathrm{~g}, 2.38 \mathrm{mmol})$ in $\mathrm{CH}_{2} \mathrm{Cl}_{2}$ $(10 \mathrm{~mL})$ under nitrogen. After stirring for $2 \mathrm{~h}$, the reaction mixture was diluted with diethyl ether, and the resulting suspension was treated with $1.5 \mathrm{M} \mathrm{NaOH}$ solution and stirred for $10 \mathrm{~min}$. Removal of the solvent and Kugelrohr distillation of the remaining semisolid gave TFMK $3(0.70 \mathrm{~g}, 85 \%)$ as a colourless oil. ${ }^{1} \mathrm{H}$ NMR $\left(300 \mathrm{MHz}, \mathrm{CDCl}_{3}\right), \delta(\mathrm{ppm}): 5.65\left(\mathrm{dtt}, J_{1}=15.3 \mathrm{~Hz}, J_{2}=6.6 \mathrm{~Hz}\right.$, $\left.J_{3}=1.2 \mathrm{~Hz}, 1 \mathrm{H}\right) ; 5.47\left(\mathrm{dtt}, J_{1}=15.3 \mathrm{~Hz}, J_{2}=6.6 \mathrm{~Hz}, J_{3}=1.2 \mathrm{~Hz}\right.$, $1 \mathrm{H}) ; 5.35(\mathrm{~m}, 2 \mathrm{H}) ; 3.42(\mathrm{~d}, J=6.6 \mathrm{~Hz}, 2 \mathrm{H}) ; 2.02(\mathrm{~m}, 6 \mathrm{H}) ; 1.33$ (bs, $18 \mathrm{H}) ; 0.89(\mathrm{t}, J=6.9 \mathrm{~Hz}, 3 \mathrm{H}) .{ }^{13} \mathrm{C} \mathrm{NMR}\left(75 \mathrm{MHz} \mathrm{CDCl}_{3}\right), \delta(\mathrm{ppm})$ : $189.8\left(\mathrm{q}, J=35 \mathrm{~Hz},-\mathrm{COCF}_{3}\right) ; 137.8 ; 129.9(2 \times) ; 117.6 ; 115.6$ (q, $\left.J=291 \mathrm{~Hz},-\mathrm{COCF}_{3}\right) ; 40.0 ; 32.5 ; 32.0 ; 29.7 ; 29.5 ; 29.5 ; 29.4 ; 29.3$; $29.1 ; 28.9 ; 27.2 ; 26.9 ; 22.3 ; 14.0 .{ }^{19} \mathrm{~F} \mathrm{NMR}\left(282 \mathrm{MHz}, \mathrm{CDCl}_{3}\right), \delta$ (ppm): -79.2 (s, COCF $)$. IR (film, NaCl) v: 3006, 2926, 2854, 1766, 1466, $1209,1148,1005,967,708 \mathrm{~cm}^{-1}$. MS (EI) $\mathrm{m} / \mathrm{z}(\%): 346\left(\mathrm{M}^{+}, 4\right) ; 277$ (4); 138 (16); 97 (17); 96 (22); 95 (28); 83 (31); 82 (31); 81 (36); 69 (43); 55 (100); 43 (24); 41 (39). Elemental analysis: Calcd for $\mathrm{C}_{20} \mathrm{H}_{33} \mathrm{~F}_{3} \mathrm{O}$ : C, 69.33, H, 9.60; F, 16.45. Found: C, 69.19; H, 9.69; F, 16.53 .

\subsection{6 (E)-1,1,1-Trifluoro-4-eicosen-2-ol (13)}

This compound was obtained as previously described for dienol 12. Starting from 1 -octadecene $(11)(0.50 \mathrm{~g}, 1.98 \mathrm{mmol})$, trifluoroacetaldehyde ethyl hemiacetal $(0.23 \mathrm{~mL}, 1.98 \mathrm{mmol})$ and $\mathrm{BF}_{3} \cdot \mathrm{OEt}_{2}(0.75 \mathrm{~mL}, 5.94 \mathrm{mmol})$ in anhydrous $\mathrm{CH}_{2} \mathrm{Cl}_{2}(3 \mathrm{~mL})$, trifluoromethyl carbinol $13(0.52 \mathrm{~g}, 75 \%)$ was obtained in an
88:12 $E: Z$ ratio after purification by column chromatography (silica gel, hexane : ether $98: 2$ ). Stereochemically pure $E, Z$ isomer $(0.42 \mathrm{~g}, 61 \%)$ was obtained after column chromatography on silica gel impregnated with $10 \% \mathrm{AgNO}_{3},{ }^{24}$ eluting with hexane:ether (98: 2). ${ }^{1} \mathrm{H}$ NMR $\left(300 \mathrm{MHz}, \mathrm{CDCl}_{3}\right), \delta$ (ppm): 5.65 (dtt, $J_{1}=15.3 \mathrm{~Hz}$, $\left.J_{2}=6.6 \mathrm{~Hz}, J_{3}=1.2 \mathrm{~Hz}, 1 \mathrm{H}\right) ; 5.40\left(\mathrm{dt}, J_{1}=15.3 \mathrm{~Hz}, J_{2}=6.9 \mathrm{~Hz}\right.$, $1 \mathrm{H}) ; 3.92(\mathrm{~m}, 1 \mathrm{H}) ; 2.38(\mathrm{~m}, 3 \mathrm{H}) ; 2.04(\mathrm{~m}, 2 \mathrm{H}) ; 1.32(\mathrm{bs}, 26 \mathrm{H}) ; 0.88(\mathrm{t}$, $J=6.6 \mathrm{~Hz}, 3 \mathrm{H}) .{ }^{13} \mathrm{C} \mathrm{NMR}\left(75 \mathrm{MHz}, \mathrm{CDCl}_{3}\right), \delta(\mathrm{ppm}): 136.8 ; 124.9$ $\left(\mathrm{q}, J=280 \mathrm{~Hz}, \mathrm{CH}(\mathrm{OH}) \mathrm{CF}_{3}\right) ; 122.5 ; 69.7$ (q, J= $\left.31 \mathrm{~Hz}, \mathrm{CH}(\mathrm{OH}) \mathrm{CF}_{3}\right)$; $33.3 ; 32.6 ; 31.9 ; 29.7 ; 29.7 ; 29.6 ; 29.5 ; 29.4 ; 29.2 ; 29.2 ; 22.7 ; 14.1 .{ }^{19} \mathrm{~F}$ $\operatorname{NMR}\left(282 \mathrm{MHz}, \mathrm{CDCl}_{3}\right), \delta(\mathrm{ppm}):-79.8\left(\mathrm{~d}, J=6.8 \mathrm{~Hz}, \mathrm{CH}(\mathrm{OH}) \mathrm{CF}_{3}\right)$. IR (film, NaCl) v: 3406, 3004, 2922, 2853, 1463, 1277, 1170, 1134, 970, 909, 733, $698 \mathrm{~cm}^{-1}$. MS (EI) $\mathrm{m} / \mathrm{z}(\%): 350\left(\mathrm{M}^{+}, 2\right) ; 139(19) ; 125$ (19); 111 (39); 97 (69); 83 (83); 69 (51); 57 (100); 55 (79); 43 (74); 41 (51).

\subsection{7 (E)-1,1,1-Trifluoro-4-eicosen-2-one (5)}

This compound was obtained as previously described for TFMK 3. Starting from dienol $\mathbf{1 3}(2.52 \mathrm{~g}, 7.19 \mathrm{mmol})$ and a $15 \%$ solution of Dess-Martin reagent ${ }^{25}$ in $\mathrm{CH}_{2} \mathrm{Cl}_{2}(51.00 \mathrm{~g}, 17.97 \mathrm{mmol})$, TFMK $5(2.16 \mathrm{~g}, 86 \%)$ was obtained after Kugelrohr distillation as a colourless oil. ${ }^{1} \mathrm{H}$ NMR $\left(300 \mathrm{MHz}, \mathrm{CDCl}_{3}\right), \delta$ (ppm): 5.65 (dtt, $\left.J_{1}=15.3 \mathrm{~Hz}, J_{2}=6.6 \mathrm{~Hz}, J_{3}=1.2 \mathrm{~Hz}, 1 \mathrm{H}\right) ; 5.47\left(\mathrm{dt}, J_{1}=15.3 \mathrm{~Hz}\right.$, $\left.J_{2}=6.6 \mathrm{~Hz}, 1 \mathrm{H}\right) ; 3.42(\mathrm{~d}, J=6.6 \mathrm{~Hz}, 2 \mathrm{H}) ; 2.06(\mathrm{~m}, 2 \mathrm{H}) ; 1.32$ (bs, $26 \mathrm{H}) ; 0.88(\mathrm{t}, J=6.6 \mathrm{~Hz}, 3 \mathrm{H}) .{ }^{13} \mathrm{C}$ NMR $\left(75 \mathrm{MHz} \mathrm{CDCl}_{3}\right), \delta(\mathrm{ppm})$ : 189.7 (q, $J=34 \mathrm{~Hz}, \mathrm{COCF}_{3}$ ); $137.8 ; 117.6 ; 115.6$ (q, $J=291 \mathrm{~Hz}$, $\left.\mathrm{COCF}_{3}\right) ; 40.0 ; 32.6 ; 32.0 ; 29.7 ; 29.6 ; 29.5 ; 29.4 ; 29.1 ; 29.0 ; 22.7 ; 14.1$. ${ }^{19} \mathrm{~F} \mathrm{NMR}\left(282 \mathrm{MHz}_{1} \mathrm{CDCl}_{3}\right), \delta(\mathrm{ppm}):-79.2\left(\mathrm{~s}, \mathrm{COCF}_{3}\right) . \mathrm{IR}(\mathrm{film}, \mathrm{NaCl})$ $v: 3004,2926,1765,1463,1208,1151,1006,968 \mathrm{~cm}^{-1}$. MS (EI) $\mathrm{m} / \mathrm{z}$ (\%): $348\left(\mathrm{M}^{+}, 1\right) ; 279(11) ; 138$ (100); 97 (45); 83 (59); 69 (64); 57 (95); 55 (24); 43 (72); 41 (40). Elemental analysis: Calcd for $\mathrm{C}_{20} \mathrm{H}_{35} \mathrm{~F}_{3} \mathrm{O}: \mathrm{C}_{\text {, }}$ 68.93; $H, 10.12 ; F, 16.36$. Found: $C, 69.04 ; H, 10.31 ; F, 16.23$.

\subsection{Adults of Zeuzera pyrina}

Adults of $Z$. pyrina were obtained from a population originated from larvae collected in the fruit-growing area of Lleida (northeastern Spain). The larvae were reared on a semi-synthetic $\operatorname{diet}^{26}$ at $25 \pm 5^{\circ} \mathrm{C}$ under a $16: 8 \mathrm{~h}$ light: dark photoperiod at the Centre UdL-IRTA for R\&D (Lleida, Spain). The larvae were kept in cylindrical plastic boxes in groups of five during the first-development instars, and they were isolated during their last two instars. Pupae were separated by sex, and males and females were kept under the above-mentioned conditions in different environmental chambers until adult emergence. Males and females less than 4 days old were used in the experiments, as in previous unpublished studies the authors had found that $Z$. pyrina females only called and males were only active during the first 3 days after emergence.

\subsection{TFMK activity assays}

\subsubsection{Electrophysiology}

To test the inhibitory effect of the TFMKs, the response to pheromone stimuli of antennae previously treated with TFMKs was compared with the response of untreated antennae of the same individual. Twelve males were slightly anaesthetised with ice for 5-10 $\mathrm{min}$, and a hexane solution $\left(0.5 \mu \mathrm{L}, 0.02-2 \mu \mathrm{g} \mu \mathrm{L}^{-1}\right)$ of TFMK $\mathbf{3}$ or $\mathbf{4}$ or hexane alone was topically applied to one of their antennae. After $5 \mathrm{~min}$ at room temperature to allow males to recover, the antennae were excised and their last segments were cut. The antennae were then fixed to the electrodes with conducting gel Spectra 360 (Parker Lab. Inc., Hellendoorn, The 
Netherlands). A flow of humidified pure air $\left(1000 \mathrm{~mL} \mathrm{~min}^{-1}\right)$ was continuously directed over the male antenna through the main branch of a glass tube $(7 \mathrm{~cm}$ long $\times 5 \mathrm{~mm}$ diameter). Test stimuli were carried out by giving $8-10$ puffs of air $\left(300 \mathrm{~mL} \mathrm{~min}^{-1}\right)$ for $100 \mathrm{~ms}$ at $40 \mathrm{~s}$ intervals through a Pasteur pipette with a CS01 stimulus controller (Syntech). The pipette contained a small piece of filter paper $(2 \times 1 \mathrm{~cm})$ on which $10 \mu \mathrm{g}$ of the pheromone blend had been deposited. This amount was chosen after previous experiments had shown that it provoked, in the present conditions, a response of $1.57 \pm 0.33 \mathrm{mV}$ ( $n=22$, unpublished data), the highest mean response observed in the range tested $(0.3-30 \mu \mathrm{g}$ of pheromone). Control puffs with a piece of paper containing only solvent (hexane) were interposed between two consecutive puffs to determine the baseline depolarisation of the antennae. The signals were amplified $(100 \times)$ and filtered (DC to $1 \mathrm{kHz})$ with an IDAC-2 interface (Syntech), digitised on a PC and analysed with the EAG Pro program. The response inhibition of each TFMK and dose tested was calculated as the percentage of the response of the treated antenna relative to that of the untreated one. The inhibition values were analysed by one-way ANOVA followed by a Duncan's multiple range test $(P<0.05)$, using the SAS system (v.8).

\subsubsection{Wind tunnel}

The experiments were carried out in glass wind tunnels previously described, ${ }^{27,28}$ located at the Spanish National Research Council in Barcelona and at the University of Lleida (Spain).

\subsubsection{Bioassay procedure}

The general conditions of the experiments were: average temperature inside the tunnel, $23 \pm 2{ }^{\circ} \mathrm{C}$; relative humidity, $60 \%$; illumination with red light bulbs, $1-3 \mathrm{lux}$; wind speed, $0.2 \mathrm{~m} \mathrm{~s}^{-1}$; time of day, from the beginning of the scotophase to $2 \mathrm{~h}$ later. The males were maintained in the wind tunnel room for $30 \mathrm{~min}$ prior to the experiments for acclimatisation. The males were individually placed on a $25 \mathrm{~cm}$ high platform that was placed $130 \mathrm{~cm}$ apart from the emission source. They were allowed $10 \mathrm{~min}$ to respond to the stimulus, and four behavioural responses were recorded: take-off (TO: the male left the platform and started to fly); half-way (HW: upwind flight until arrival to the middle of the wind tunnel); complete flight (CF: upwind flight to the proximity of the source); source contact (SC: touchdown with the emission source). Twentytwo males were used for the experiments. Each male was used several times owing to the difficulties of obtaining adults in the laboratory. No statistical analysis was carried out, therefore, as the samples were not independent.

\subsubsection{Pheromone assays}

To determine the male response to the sex pheromone, males were flown to a virgin calling female that had been placed inside a metal cage at the same height as the insect release platform.

\subsubsection{Inhibition assays}

Only the effect of TFMK 4 was investigated. For the tests, different amounts $(0.1,1,5$ and $10 \mu \mathrm{g})$ of TFMK 4 were deposited on a filter paper $(2 \times 2 \mathrm{~cm})$ that was placed $1 \mathrm{~cm}$ apart from the calling female. Each male was flown first only to the calling female and to both the female and the inhibitory component simultaneously afterwards.

\subsubsection{Flight tracks}

Tracks of flying insects were recorded with a CCD 2400JB Presentco video camera (Rister, Barcelona, Spain) equipped with a $12 \mathrm{~mm}$ wide-angle lens. The camera was mounted at a height of $140 \mathrm{~cm}$ above the tunnel in a perpendicular position to record the insect flight with a minimal optical distortion. The camera covered a $130 \times 45 \mathrm{~cm}$ section of the tunnel, and the recorded tracks were sent to a monitor for visualisation. The tracks were converted into computer files at a rate of 25 frame $\mathrm{s}^{-1}$ with the aid of digital video software (Pinnacle Systems 5.1, Mountain View, CA). The successive insect positions were converted into $X Y$ coordinates using in-house software, and they were plotted in graphs at $0.4 \mathrm{~s}$ intervals. Only uninterrupted flights were considered.

\subsubsection{Field tests}

Field tests were carried out in 2003 and 2004 in infested apple and olive orchards in the fruit-growing areas of Lleida and Girona (Catalonia, north-eastern Spain) during the flight period of $Z$. pyrina males (from mid-May to early September). Mixtures of the pheromone and compounds $\mathbf{3 , 4}, \mathbf{5}$ and $\mathbf{6}$ at $1: 1$ and $1: 5$ ratios were obtained by adding the required amount of the inhibitor to $5 \mathrm{mg}$ of the pheromone. Dispensers containing only $5 \mathrm{mg}$ of the pheromone were used as controls. Polyethylene vials and $36 \times 20 \mathrm{~cm}$ delta traps were used. Traps were hung over the canopy of the crop and spaced $20 \mathrm{~m}$ from each other; the dispensers and the traps were changed once during the tests. The position of the traps was rotated once per week, and the trials finished after two complete rotations of trap position had been carried out. Three replicates per formulation were carried out. A fully randomised block design was used. The total number of catches was treated with a one-way ANOVA, and the mean number of catches was compared with a Duncan's multiple range test $(P<0.05)$ using the SAS system (v.8).

\section{RESULTS AND DISCUSSION}

\subsection{Synthesis}

The main features of the major pheromone compound of the leopard moth are the presence of two unsaturations at positions 2 and 13 in the aliphatic chain. Therefore, it was essential for the TMKs considered as possible inhibitors to contain both double bonds at the same position and with the same stereochemistry.

Although several methods have been developed for the synthesis of TFMKs, ${ }^{19,20,29-34}$ in the case of allylic TFMKs $\mathbf{3}$ and $\mathbf{5}$ new problems arose owing to the enhanced reactivity of the allylic methylene group in the $\alpha$-position to the carbonyl. For preparation of these compounds, the authors initially tried to introduce the double bond at position 3 by desulfonation of the $\alpha$-phenylsulfonyl derivative, but preparation of this compound failed. ${ }^{18}$ Also, reaction of the carboxylic acid precursor with an electrophile ${ }^{31}$ or trans-metallation of the corresponding 1-iodo-2-alkadiene with tert-butyllithium ${ }^{19}$ were unsuccessful. The only precedent found in the literature for the synthesis of these TFMK precursors was reported by Sakumo et al.,23 who prepared fluorinated homoallyl alcohols by adding olefins to trifluoroacetaldehyde hemiacetal through an ene-type reaction. These authors used this approach to obtain trifluoromethylated dienes through dehydration of trifluoromethyl homoallyl alcohols, ${ }^{35,36}$ and only in one case did they apply this methodology to prepare an allylic TFMK $(1,1,1$ trifluoro-4-dodecen-2-one). ${ }^{37}$

The strategy followed for the preparation of TFMKs $\mathbf{3}$ and $\mathbf{5}$ is depicted in Fig. 2. Transformation of (Z)-1-bromo-11-hexadecene 

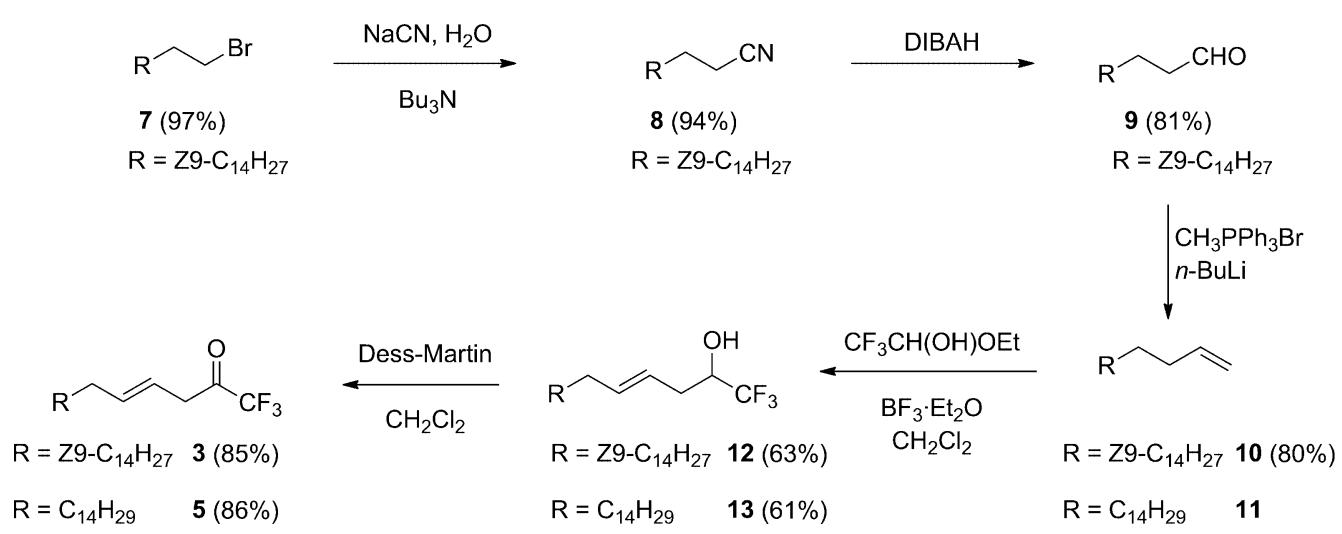

Figure 2. Synthesis of allylic trifluoromethyl ketones $\mathbf{3}$ and $\mathbf{5}$.
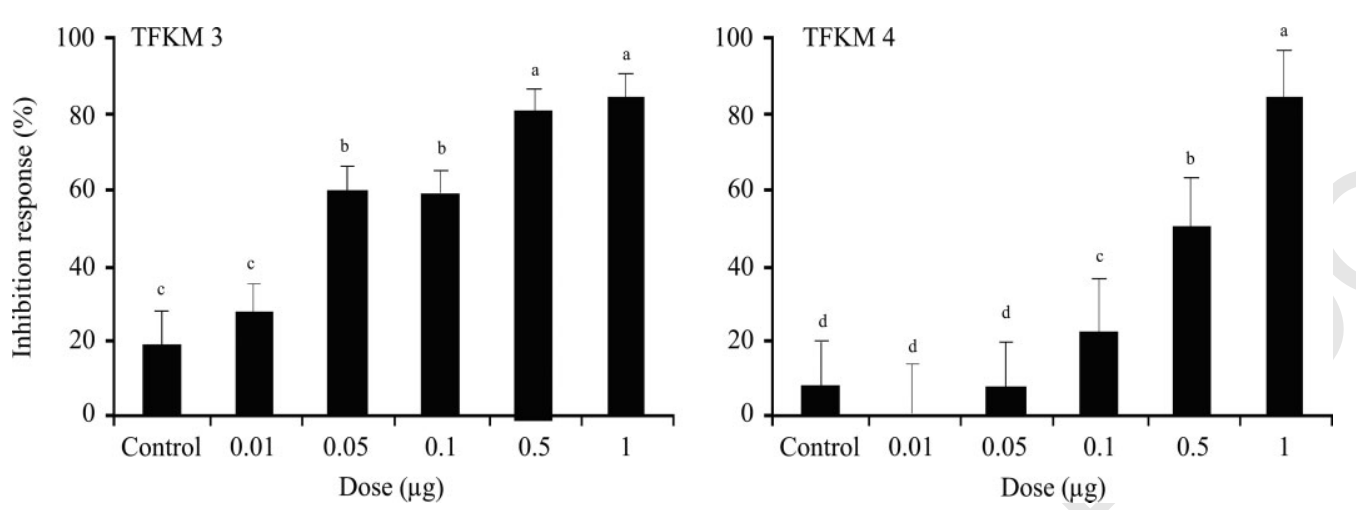

Figure 3. Inhibition of the EAG response of Zeuzera pyrina males to the sex pheromone after topical application of different doses of TFMK $\mathbf{3}$ (left) or TFMK 4 (right). Bars with the same letter are not significantly different (Duncan's multiple range test, $P<0.05$ ).

(7) into nitrile 8 was accomplished by reaction with aqueous sodium cyanide in the presence of tributylamine as phase transfer catalytic agent. ${ }^{22}$ Compound $\mathbf{8}$ was reduced to aldehyde $\mathbf{9}$ under standard conditions (DIBAH/hexane), and Wittig reaction of 9 with methyltriphenylphosphonium ylide afforded diene 10 in good yield. At this point, diene 10 and commercial 1octadecene (11) were used as starting materials for the ene reaction with trifluoroacetaldehyde ethyl hemiacetal and boron trifluoride etherate as Lewis acid. After $4 \mathrm{~h}$ at room temperature, the reaction was completed, affording the desired homoallyl alcohols 12 and 13 in $63 \%$ and $61 \%$ yields respectively. Under these conditions, the disubstituted double bond of $\mathbf{1 2}$ at position 13 remained untouched, pointing out the regioselective character of the reaction. Another important point is the diastereoselectivity of this reaction. The process occurs through an anti-elimination mechanism to form the $E$ isomer predominantly. The $E: Z$ isomeric ratio of the new double bond formed was $86: 14$ for alcohol 12 and $88: 12$ for alcohol $\mathbf{1 3}$. This remarkable diastereoselectivity made it possible to obtain the stereochemically pure ( $\geq 98 \%) E$ isomers by column chromatography on $\mathrm{AgNO}_{3}$-impregnated silica gel. In addition, an excellent $98 \%$ of the $E$ isomer was recovered. Finally, mild oxidation of alcohols $\mathbf{1 2}$ and $\mathbf{1 3}$ with the Dess -Martin reagent afforded allylic TFMKs $\mathbf{3}$ and $\mathbf{5}$ in $85-86 \%$ yields.

Homoallylic TFMK $\mathbf{4}$ was also prepared because it was closely structurally related to the minor pheromone component $\mathbf{2}$. Monoene TFMK 6, in turn, was considered to evaluate the importance of the unsaturation at position 2 or 3 on the inhibition activity. Both compounds $\mathbf{4}$ and $\mathbf{6}$ were obtained following a procedure previously described by the present authors. ${ }^{19}$ The retention times of the pheromone components $\mathbf{1}$ and $\mathbf{2}$ and the TFMKs 3 to 6 on an HP5 column $(30 \mathrm{~m} \times 0.25 \mathrm{~mm} \times 0.25 \mu \mathrm{m})(\mathrm{GC}$ conditions: injection at $120^{\circ} \mathrm{C}$ for $1 \mathrm{~min}$ and programmed rise in temperature at $3^{\circ} \mathrm{C} \mathrm{min}-1$ until $280{ }^{\circ} \mathrm{C}$ for $10 \mathrm{~min}$ ) were: $(E, Z)-\mathbf{1}$, $32.33 \mathrm{~min}$; $(E, Z)-\mathbf{2}, 31.86 \mathrm{~min}$; $(E, Z)-3,26.18 \mathrm{~min}$; $(E, Z)-4,24.55 \mathrm{~min}$; $(E)-5,26.58 \mathrm{~min} ;(Z)-6,24.87 \mathrm{~min}$.

\subsection{TFMK activity}

\subsubsection{Electrophysiology}

When TFMKs $\mathbf{3}$ and $\mathbf{4}$ were electrophysiologically tested, both compounds showed a remarkable inhibition of the electroantennogram (EAG) responses to the pheromone (Fig. 3). In both cases the inhibition was dose dependent, and it reached values greater than $80 \%$ at the highest dose tested $\left(1.0 \mu \mathrm{g}\right.$ antenna $\left.{ }^{-1}\right)$. The effect of $\mathbf{3}$, the analogue of the major pheromone compound, was stronger than the effect of $\mathbf{4}$, the analogue of the minor pheromone compound. The inhibition caused by $\mathbf{3}$ was significantly different from the control (hexane) for doses of $\geq 0.05 \mu \mathrm{g}$ antenna $^{-1}$, and the maximum inhibition was obtained at 0.5 and $1.0 \mu \mathrm{g}$ antenna ${ }^{-1}$, whereas for $\mathbf{4}$ the inhibition was significantly different from the control (hexane) for doses 20 times greater than for $3\left(0.1 \mu \mathrm{g}\right.$ antenna $\left.{ }^{-1}\right)$, and the maximum inhibition was obtained at a dose of $1 \mu \mathrm{g}$ antenna ${ }^{-1}$. Similar results were obtained on Spodoptera littoralis Boisduval, where 3-octylthio1,1,1-trifluoropropan-2-one (OTFP) decreased the EAG amplitude and increased the repolarisation time of the pheromone response, the EAG kinetics being increased with the TFMK dose. ${ }^{38}$ Also, exposure of antennal receptors of Spodoptera frugiperda (JE Smith) to vapours of OTFP resulted in a decreased amplitude and $2 / 3$ 


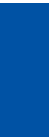

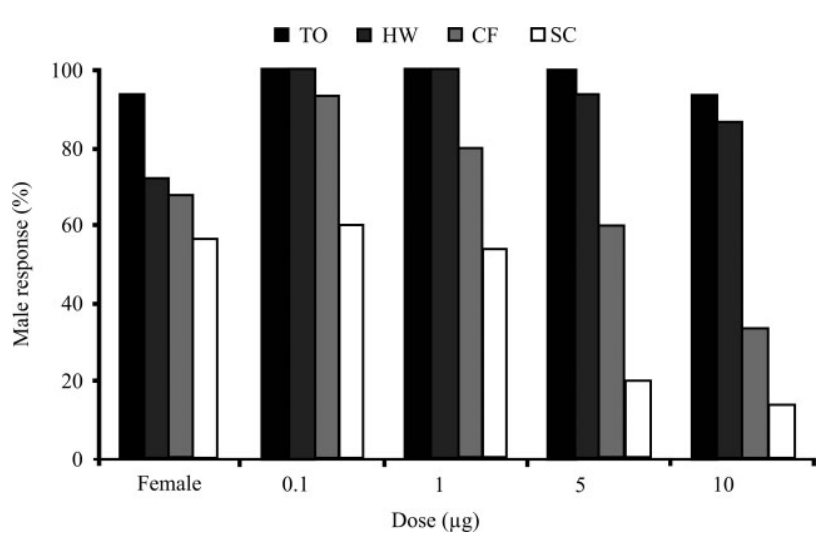

Figure 4. Response of Zeuzera pyrina males to the calling female $(n=22)$ and to the calling female in the presence of different amounts of TFMK 4 ( $n=15)$. TO: take-off; HW: half-way; CF: complete flight; SC: source contact.

repolarisation time of the EAG response to the pheromone, the effect being reversible. ${ }^{39}$ The non-fluorinated analogue (OTP) did not affect any of the EAG parameters, confirming the key role played by fluorine atoms in this type of chemical. ${ }^{39,40}$ In the European corn borer Ostrinia nubilalis (Hübner), the TFMK analogue of the major component of the pheromone inhibited the EAG response to the natural attractant in a dose-response manner, and $10 \mathrm{pg}$ of the ketone was sufficient to promote a $77 \%$ inhibition response. $^{40}$

\subsubsection{Wind tunnel}

In $95 \%$ of the cases, males took off in response to the calling female, but only in $62 \%$ of cases did they show an oriented flight towards the source, and in only $55 \%$ did they contact the female (Fig. 4). Unpublished results from the authors' group have shown that $Z$. pyrina males do not fly easily in the wind tunnel, their behaviour being highly variable (a variable number of contacts have been recorded of males tested under almost identical conditions). Nevertheless, the percentage of complete upwind flights obtained in the experiments reported here (55\%)

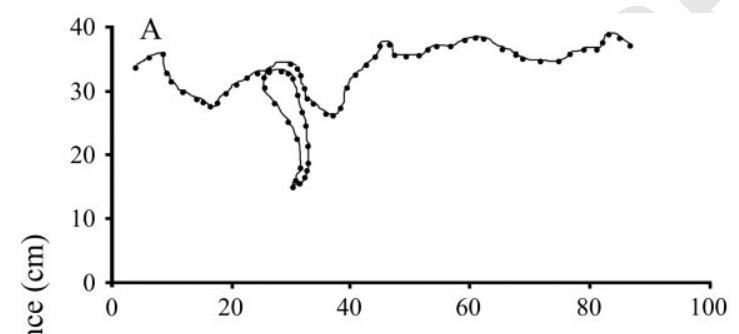

Figure 5. Track flights of Zeuzera pyrina males towards a calling female ( $\mathrm{A}$ and $C$ ) and towards a calling female in the presence of TFMK 4 at $0.1 \mu \mathrm{g}$ (B) and at $1 \mu \mathrm{g}(\mathrm{D})$. The insect moved upwind from left to right. The insect position at $0.4 \mathrm{~s}$ intervals is shown by the dark points. is high enough to detect a possible disruptant effect of the TFMKs. Although no statistical analysis could be performed, as the same males were used several times in the experiments, a change of amounts of TFMK 4, the analogue of the minor component of the pheromone, equal to or higher than $5 \mu \mathrm{g}$ was evident (Fig. 4). TFMK 4 decreased the percentage of males that showed a complete flight and contacted the female. The inhibition took place after the male had passed the middle of the tunnel, i.e. in the $\mathrm{CF}$ and SC behaviour (Fig. 4). The disrupting effect exerted by TFMK 4 was also evident when the flight tracks were video-recorded. In the presence of the inhibitor, males displayed an erratic flight (or less oriented in the presence of the lower dose of the TFMK, flight A versus flight $B$ in Fig. 5) to the source, in contrast to the much more oriented flight onto the plume that was shown by control insects (flight $C$ versus flight $D$ in Fig. 5). Consequently, flight tracks were longer when the TFMK 4 was present in the lure than when the female was alone. These results agree with those previously obtained on Sesamia nonagrioides Lefevre ${ }^{16}$ and O. nubilalis, ${ }^{41}$ when males were attracted to mixtures of the TFMK analogues of the pheromone and the natural attractant in $5: 1$ and $10: 1$ ratios, confirming the disruptant effect of these chemicals in different moth species.

\subsubsection{Field tests}

The activity of the synthetic compounds in the field was determined by evaluating the number of insects caught with blends of pheromone: TFMK. In 2003, the dienic TFMK 4 displayed the highest inhibition activity among the three compounds tested (4 to 6) (Fig. 6). Compound 6, which lacks the unsaturation at position 2, was a stronger inhibitor than 5, which lacks the unsaturation at position 13 , and the difference was significant at the two ratios tested. These results were confirmed at a pheromone : inhibitor ratio of $1: 1$ in the 2004 trial at Lleida Fuliola (Fig. 7). From these results, the conclusions drawn are twofold: firstly, the most closely related analogue of one of the pheromone components is the best inhibitor; secondly, the presence of the double bond at position 13 plays a crucial role in the activity of
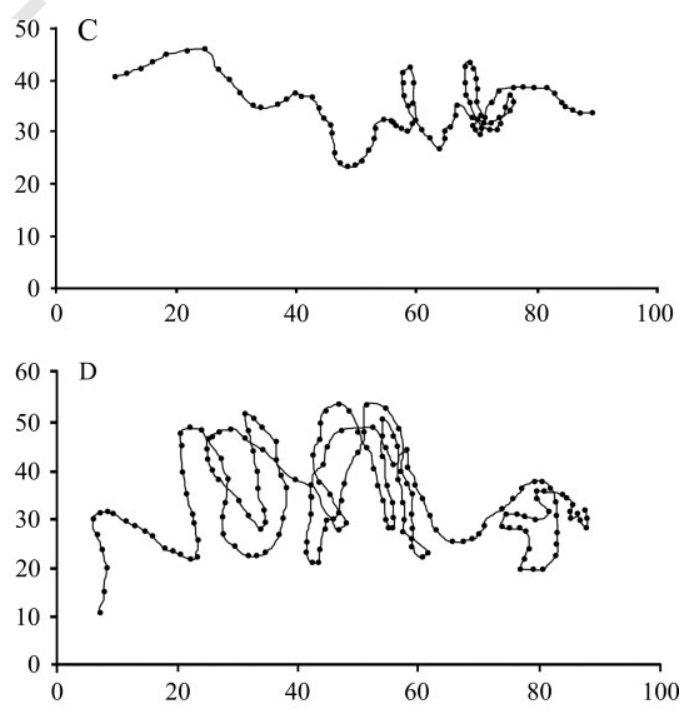
in their behaviour towards the calling females in the presence 


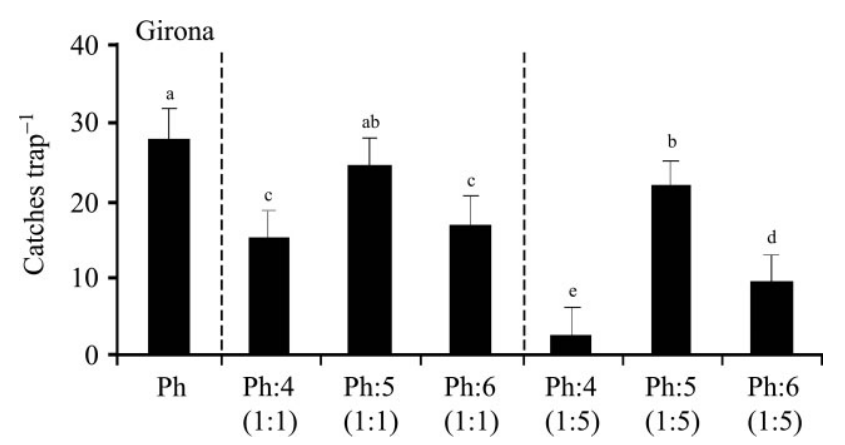

Figure 6. Field catches of Zeuzera pyrina males in traps placed on infested olive trees in Girona in 2003. Traps were baited with mixtures of pheromone and TFMKs 4 to 6 in 1:1 and 1:5 ratios. The amount of pheromone in each trap was $5 \mathrm{mg}$. Bars with the same letter are not significantly different (Duncan's multiple range test, $P<0.05$ ).

these chemicals. In 2004, the authors compared the activity of the dienic compounds $\mathbf{3}$ and $\mathbf{4}$ in three field trials. Except in one case, the addition of TFMKs $\mathbf{3}$ and $\mathbf{4}$ reduced significantly the total number of catches, and reductions higher than $90 \%$ were achieved (Fig. 7). However, it was not clear whether compound $\mathbf{3}$, the analogue of the major component of the pheromone, was a stronger inhibitor than $\mathbf{4}$, the analogue of the minor component. The high variability of the number of catches probably prevented the detection of significant differences. The observed trend was different in Girona, where $\mathbf{3}$ seemed to be more effective than in Lleida, where $\mathbf{4}$ appeared to be more effective. A mixture of TFMKs 3 and 4 in the same ratio $(96: 4)$ as the corresponding components in the pheromone blend did not result in a significant difference in activity in comparison with the major analogue $\mathbf{3}$ alone. The present field results confirm the antagonist activity of other TFMK analogues of the pheromone that was previously recorded on S. nonagrioides, ${ }^{16}$ O. nubilalis ${ }^{40,41}$ and Cydia pomonella (L.). ${ }^{17}$ Moreover, in large-scale field experiments, application of (Z)-11-hexadecenyl trifluoromethyl ketone, an analogue of the $S$. nonagrioides pheromone, yielded a noticeable reduction in

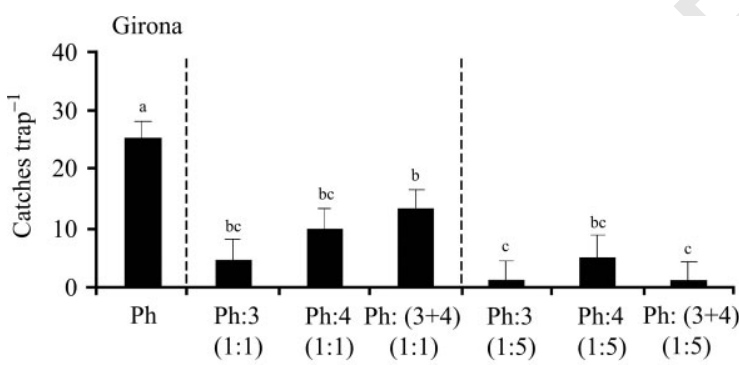

damage caused by this pest and by the sympatric species $O$. nubilalis, both in the number of plants attacked and in the number of larvae found per plant. ${ }^{42}$

Pheromone inhibitors, as analogues of the natural pheromones, have been used in mating disruption experiments for pest control. ${ }^{43}$ The present authors have demonstrated in recent years that TFMKs are potent antagonists of the pheromone in the field and good inhibitors in electrophysiology and behaviour in the laboratory. ${ }^{16,17,38-42}$ In addition, although it has not been determined in antennal extracts of $Z$. pyrina, these chemicals displayed a remarkable antiesterase activity in S. littoralis, ${ }^{11,14}$ S. nonagrioides ${ }^{44}$ and $O$. nubilalis. ${ }^{38}$ Antennal esterases are key enzymes for the rapid degradation of pheromone esters, and inhibition of these enzymes would induce saturation or blocking of pheromone receptors, leading to a decreased capability of the insect to detect new incoming pheromone molecules. TFMKs can also bind to pheromone-binding proteins (PBPs) in competition with pheromone molecules, ${ }^{45,46}$ as shown in binding experiments by displacement of the major component of the pheromone of Mamestra brassicae Linné by (Z)-11-16:trifluoromethyl ketone. ${ }^{47}$ TFMKs have shown low toxicity in Swiss mice, e.g. (Z)-11hexadecenyl trifluoromethyl ketone and OTFP displayed an $\mathrm{LD}_{50}$ of $1 \mathrm{~g} \mathrm{~kg}^{-1}$ body weight after 6 days of treatment, whereas the pheromone showed an $\mathrm{LD}_{50}$ of $5 \mathrm{~g} \mathrm{~kg}^{-1}$ body weight. ${ }^{16}$ These data agree with a previous report in which doses of up to $250 \mathrm{mg} \mathrm{kg}^{-1}$ body weight of some fluorinated ketones for over 3 months caused no mortality on Swiss Webster mice. ${ }^{48}$ Also, it has been found in aquatic ecotoxicity studies that (Z)-11-hexadecenyl trifluoromethyl ketone was only moderately toxic, with $\mathrm{EC}_{50}$ values ranging from 3.11 to $103.7 \mathrm{mg} \mathrm{L}^{-1}$ in algae growth, and from 0.07 to $1.2 \mathrm{mg} \mathrm{L}^{-1}$ in Daphnia survival. ${ }^{49}$ The low toxicity elicited by these compounds is possibly due to their reversible inhibition mechanism, in contrast to the much higher toxicity displayed by other irreversible inhibitors of carboxylesterases and proteases. The results accumulated so far suggest that new studies on the threshold activity of TFMKs are worthwhile in order to evaluate the real prospects of their use as new possible pest control agents.

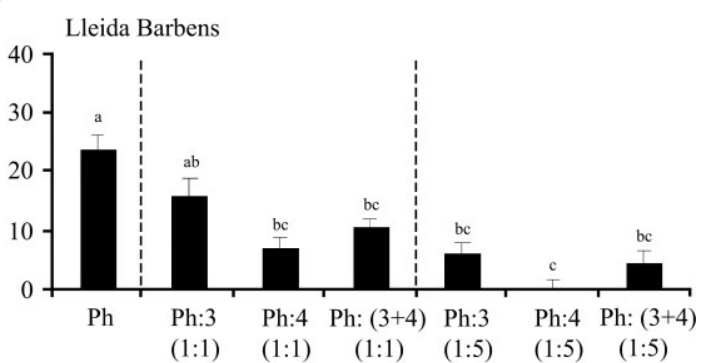

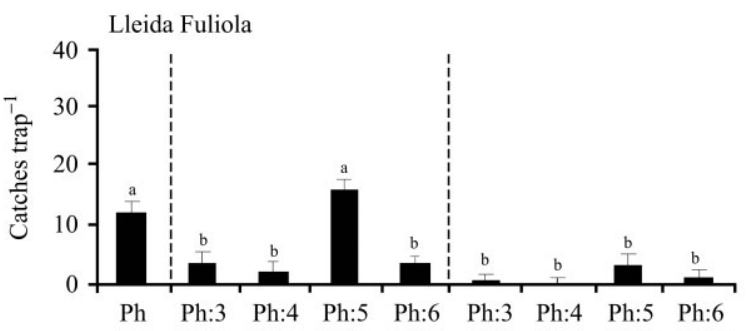

$(1: 1) \quad(1: 1) \quad(1: 1) \quad(1: 1) \quad(1: 5) \quad(1: 5) \quad(1: 5) \quad(1: 5)$

Figure 7. Field catches of Zeuzera pyrina males in traps placed on infested apple and olive trees in Lleida and Girona, respectively, in 2004. Traps were baited with mixtures of pheromone and TFMKs 3 to 6 in $1: 1$ and $1: 5$ ratios. The amount of pheromone in each trap was 5 mg. Bars with the same letter are not significantly different (Duncan's multiple range test, $P<0.05$ ). 


\section{CONCLUSION}

Efficient syntheses of allylic TFMKs, analogues of the two components of the pheromone of the leopard moth, have been accomplished in good yields, regiospecificity and diastereoselectivity. The most closely related analogues of both pheromone components are good inhibitors of the natural attractant both in the laboratory and in the field. The presence of an unsaturation at positions 2 and 13 in the structure of these analogues is crucial for optimum activity.

\section{ACKNOWLEDGEMENTS}

The authors acknowledge the EC (Biosynthetic Infochemical Communication project, contract 032275) for a contract to LM, and SEDQ SA for free samples of (Z)-13-hexadecenal, $(Z, E)-3,13-$ octadecadienol and (Z)-11-hexadecen-1-ol. This work was also partially financed by grants AGL2004-05812/AGR and AGL200613489-C02-01/AGR (Spanish Ministry for Education and Science). The authors are grateful to T Calvo and A Palerm for their technical support, and to N Varela for help in writing the manuscript.

\section{REFERENCES}

1 Tonini C, Cassani G, Massardo P, Guglielmetti G and Castellari PL, Study of female sex pheromone of leopard moth, Zeuzera pyrina L. Isolation and identification of three components. J Chem Ecol 12:1545-1558 (1986).

2 Malosse $C$, Descoins $C$ and Frérot $B$, Identification of a minor component of the sex pheromone of the leopard moth (Zeuzera pyrina L.; Lepidoptera, Cossidae) by capillary gas chromatography. J High Res Chrom 16:123-125 (1993).

3 Capdevila A, Prasad AR, Quero C, Petschen I, Bosch MP and Guerrero A, A convergent and highly efficient synthesis of $(E, Z)-2,13-$ octadecadienyl acetate and $(E, Z)$-3,13-octadecadienyl acetate, components of the sex pheromone of the leopard moth Zeuzera pyrina, through sulfones. Org Lett 1:845-848 (1999).

4 Haniotakis GE, Koutroubas A, Sachinoglou A and Lahlou A, Studies on the response of the leopard moth, Zeuzera pyrina L. (Lepidoptera, Cossidae), to pheromone in apple orchards. IOBC WPRS Bull 22:105-113 (1999).

5 Pasqualini E and Natale D, Zeuzera pyrina and Cossus cossus (Lepidoptera, Cossidae) control by pheromones: four years advances in Italy orchards. IOBC WPRS Bull 22:115-124 (1999).

6 Hegazi E, Khafagi WE, Konstantopoulou M, Raptopoulos D, Tawfik H, Abdel-AzizGM, etal, Efficient mass-trapping method as an alternative tactic for suppressing populations of leopard moth (Lepidoptera: Cossidae). Ann Entomol Soc Am 102:809-818 (2009).

7 Escofet M, Boada J, Melo JC, Casals C, Barrios G, Palau R, et al, Sexual disruption to control leopard moth (Zeuzera pyrina) in hazelnut. Acta Hort 686:421-426 (2005).

8 Gelb MH, Svaren JP and Abeles RH, Fluoro ketone inhibitors of hydrolytic enzymes. Biochemistry 24:1813-1817 (1985).

9 Ashour M-BA and HammockBD, Substituted trifluoroketones as potent selective inhibitors of mammalian carboxylesterases. Biochem Pharm 36:1869-1879 (1987).

10 Prestwich GD, Chemical studies of pheromone receptors in insects. Arch Insect Biochem Physiol 22:75-86 (1993).

11 Durán I, Parrilla A, Feixas J and Guerrero A, Inhibition of antennal esterases of the Egyptian armyworm Spodoptera littoralis by trifluoromethyl ketones. Bioorg Med Chem Lett 3:2593-2598 (1993).

12 Parrilla A, Villuendas I and Guerrero A, Synthesis of trifluoromethyl ketones as inhibitors of antennal esterases of insects. Bioorg Med Chem 2:243-252 (1994).

13 Linderman RJ, Leazer J, Roe RM, Venkatesh K, Selinsky BS and London $\mathrm{RE},{ }^{19} \mathrm{~F}$ NMR spectral evidence that 3-octylthio-1,1,1trifluoropropan-2-one, a potent inhibitor of insect juvenile hormone esterase, functions as a transition state analog inhibitor of acetylcholinesterase. Pestic Biochem Physiol 31:187-194 (1988).

14 Rosell G, Herrero S and Guerrero A, New trifluoromethyl ketones as potent inhibitors of esterases: ${ }^{19} \mathrm{~F}$ NMR spectroscopy of transition state analog complexes and structure-activity relationships. Biochem Biophys Res Commun 226:287-292 (1996).

15 Guerrero A and Rosell G, Biorational approaches for insect control by enzymatic inhibition. Curr Med Chem 12:461-469 (2005).

16 Riba M, Sans A, Bau P, Grolleau G, Renou M and Guerrero A, Pheromone response inhibitors of the corn stalk borer Sesamia nonagrioides. Biological evaluation and toxicology. J Chem Ecol 27:1879-1897 (2001).

17 Giner M, Sans A, Riba M, Bosch D, Gago R, Rayo J, et al, Development and biological activity of a new antagonist of the pheromone of the codling moth Cydia pomonella. J Ag Food Chem 57:8514-8519 (2009).

18 Muñoz L, Rosa E, Bosch MP and Guerrero A, A new, practical and efficient sulfone-mediated synthesis of trifluoromethyl ketones from alkyl and alkenyl bromides. Tetrahedron Lett 46:3311-3313 (2005).

19 Villuendas I, Parrilla A and Guerrero A, An efficient and expeditious synthesis of functionalized trifluoromethyl ketones through lithium-iodine exchange reaction. Tetrahedron 50:12 673-12684 (1994).

20 Bégué JP and Bonnet-Delpon D, Preparation of trifluoromethyl ketones and related fluorinated ketones. Tetrahedron 47:3207-3258 (1991).

21 Camps F, Gasol V and Guerrero A, A new and efficient one-pot preparation of alkyl halides from alcohols. • Synthesis 511-512 (1987).

22 Apparu M, Comet M, Leo PM, Mathieu JP, Du Moulinet A, Pasqualini R, et al, Méthode de synthèse d'acides gras marqués substitués ou non en alpha et en beta. Bull Soc Chim •Fr 118-124 (1988).

23 Sakumo K, Kuki N, Kuno T, Takagi T, Koyama M, Ando A, et al, Ene-type reaction of trifluoroacetaldehyde hemiacetal with ene compounds in the presence of a Lewis acid. J Fluorine Chem 93:165-170 (1999).

24 Cert A and Moreda W, New method of stationary phase preparation for silver ion column chromatography: application to the isolation of steroidal hydrocarbons in vegetable oils. J Chromatogr $A$ 823:291-297 (1998).

25 Dess DB and Martin JC, A useful 12-I-5 triacetoxyperiodinane (the Dess-Martin periodinane) for the selective oxidation of primary or secondary alcohols and a variety of related 12-I-5 species. J Am Chem Soc 113:7277-7287 (1991).

26 Pons X, Eizaguirre M, Sarasúa MJ and Avilla J, Influencia del fotoperiodo sobre la inducción de diapausa de Cydia pomonella (L.) (Lepidoptera, Tortricidae) en laboratorio y campo. Inv Agr Prod Prot Veg 9:477-492 (1994).

27 Bau J, Martínez D, Renou M and Guerrero A, Pheromone-triggered orientation flight of male moths can be disrupted by trifluoromethyl ketones. Chem Senses 24:473-480 (1999).

28 Gemeno C, Sans A, López C, Albajes R and Eizaguirre M, Pheromone antagonism in the European corn borer moth Ostrinia nubilalis. $J$ Chem Ecol 32:1071-1084 (2006).

29 Wiedemann J, Heiner T, Mloston G, Prakash KS and Olah GA, Direct preparation of trifluoromethyl ketones from carboxylic esters: trifluoromethylation with (trifluoromethyl)trimethylsilane. Angew Chem Internat Ed 37:820-821 (1998).

30 Yokoyama $\mathrm{Y}$ and Mochida $\mathrm{K}$, Chemoselective trifluoromethylation of methyl esters using an $\mathrm{Et}_{3} \mathrm{GeNa} / \mathrm{C}_{6} \mathrm{H}_{5} \mathrm{SCF}_{3}$ combination: efficient synthesis of trifluoromethyl ketones. • Synlett 907-908 (1997).

31 Boivin J, El Kaim L and Zard SZ, A new and efficient synthesis of trifluoromethyl ketones from carboxylic acids. Tetrahedron 51:2573-2584 (1995)

32 Kim S and Kavali R, Radical-mediated synthesis of trifluoroethyl amines and trifluoromethyl ketones from alkyl iodides. Tetrahedron Lett 43:7189-7191 (2002)

33 Ryuki K, Isao S and Akio Y, Synthesis of trifluoromethyl ketones by palladium-catalyzed cross-coupling reaction of phenyl trifluoroacetate with organoboron compounds. Bull Chem Soc Jpn 74:371-376 (2001).

34 Kesavan V, Bonnet-Delpon D, Bégué JP, Srikanth A and Chandrasekaran $S$, New catalytic oxidation of trifluoromethyl carbinols by a ruthenium(II) complex. Tetrahedron Lett 41:3327-3330 (2000).

35 Nagai T, Nishioka G, Koyama M, Ando A, Miki T and Kumadaki I, Reactions of trifluoromethyl ketones. IX. Investigation of the steric effect of a trifluoromethyl group based on the stereochemistry on the dehydration of trifluoromethyl homoallyl alcohols. J Fluorine Chem 57:229-237 (1992). 
36 Nagai T, Hama M, Yoshioka M, Yuda M, Yoshida N, Ando A, et al, Reaction of trifluoromethyl ketones. V. Dehydration of trifluoromethylated homoallyl alcohols: synthesis of trifluoromethylated dienes. Chem Pharm Bull 37:177-183 (1989).

37 Ogawa K, Nagai T, Nonomura M, Takagi T, Koyama M, Ando A, et al, Studies on trifluoromethyl ketones. VII. Ene reaction of trifluoroacetaldehyde and its application for synthesis of trifluoromethyl compounds. Chem Pharm Bull 39:1707-1712 (1991).

38 Renou M, Lucas P, Malo E, Quero C and Guerrero A, Effects of trifluoromethyl ketones and related compounds on the EAG and behavioural responses to pheromones in male moths. Chem Senses 22:407-416 (1997).

39 Luis CPP, Guerrero A and Malo EA, Inhibition of electrophysiological response to the pheromone of the fall armyworm, Spodoptera frugiperda. J Pestic Sci 35:23-26 (2010).

40 Solé J, Sans A, Riba M, Rosell G, Rosa E, Muñoz L, et al, Differential activity of non-fluorinated and fluorinated analogues of the European corn borer pheromone. Chemoecology 18:99-108 (2008).

41 Riba M, Sans A, Solé J, Muñoz L, Bosch MP, Rosell G, et al, Antagonism of pheromone response of Ostrinia nubilalis males and implications on behavior in the laboratory and in the field. $J$ Ag Food Chem 53:1158-1165 (2005).

42 Solé J, Sans A, Riba M, Rosa E, Bosch MP, Barrot M, et al, Reduction of damage by the Mediterranean corn borer, Sesamia nonagrioides, and the European corn borer, Ostrinia nubilalis, in maize fields by a trifluoromethyl ketone pheromone analog. Entomol Exp Appl 126:28-39 (2008).

43 Renou Mand Guerrero A, Insect parapheromones in olfaction research and semiochemical-based pest control strategies. Annu RevEntomol 48:605-630 (2000).

44 Quero C, Rosell G, Jiménez O, Rodriguez S, Bosch MP and Guerrero A, New fluorinated derivatives as esterase inhibitors. Synthesis, hydration and crossed specificity studies. Bioorg Med Chem 11:1047-1055 (2003).

45 Feixas J, Prestwich GD and Guerrero A, Ligand specificity of pheromone-binding proteins of the processionary moth. Eur $J$ Biochem 234:521-526 (1995).

46 Pophof B, Gebauer T and Ziegelberger A, Decyl-thiotrifluoropropanone, a competitive inhibitor of moth pheromone receptors. J Comp Physiol A 186:315-323 (2000).

47 Campanacci V, Longhi S, Nagnan-Le Meillour P, Cambillau C and Tegoni M, Recombinant pheromone binding protein 1 from Mamestra brassicae (MbraPBP1). Functional and structural characterization. Eur J Biochem 264:707-716 (1999).

48 Ashour M-BA and Hammock BD, Substituted trifluoroketones as potent selective inhibitors of mammalian carboxylesterases. Biochem Pharm 36:1869-1879 (1987).

49 Rosa E, Barata C, Damásio J, Bosch MP and Guerrero A, Aquatic ecotoxicity of a pheromonal antagonist in Daphnia magna and Desmodesmus subspicatus. Aquat Toxicol 79:296-303 (2006). 


\section{QUERIES TO BE ANSWERED BY AUTHOR}

IMPORTANT NOTE: Please mark your corrections and answers to these queries directly onto the proof at the relevant place. Do NOT mark your corrections on this query sheet.

Queries from the Copyeditor:

AQ1 Volume number?

AQ2 Volume number?

AQ3 Volume number? 